\title{
Diversity, distribution, and conservation status of Rubiaceae species in Peñablanca Protected Landscape and Seascape, Luzon, Philippines
}

\author{
RACHEL D. BIAG ${ }^{1,2, \boldsymbol{v}}$, GRECEBIO JONATHAN D. ALEJANDRO ${ }^{1,3}$ \\ ${ }^{1}$ The Graduate School and Research Centre for the Natural and Applied Sciences, University of Santo Tomas. España Blvd., 1015 Manila, Philippines. \\ remail: biagrachel27ust@gmail.com, rachel.biag@yahoo.com \\ ${ }^{2}$ Department of Natural Sciences, College of Arts and Sciences, Cagayan State University. Carig Campus, Tuguegarao City, Cagayan, Philippines \\ ${ }^{3}$ Department of the Biological Sciences, College of Science, University of Santo Tomas. España Boulevard, 1015 Manila, Philippines
}

Manuscript received: 28 April 2021. Revision accepted: 8 August 2021.

\begin{abstract}
Biag RA, Alejandro GJD. Diversity, distribution, and conservation status of Rubiaceae species in Peñablanca Protected Landscape and Seascape, Luzon, Philippines. Biodiversitas 22: 3627-3636. Peñablanca Protected Landscape and Seascape (PPLS) is the largest protected area (PA) in the province of Cagayan, Luzon, Philippines. As part of the Sierra Madre Mountain Range and being contiguous with the Northern Sierra Madre Natural Park, there is no doubt that this PA would display species endemism and richness. Hence, botanical surveys through purposive sampling in seven barangays/districts were conducted in the PPLS to determine the species diversity and distribution of Rubiaceae. This study also aims to identify the endemic species and determine their conservation status. Forty-two species of Rubiaceae belonging to 19 genera and 13 tribes were documented in the current study. The most species-rich tribes are Spermacoceae (9 sp.), followed by Psychotrieae (7 sp.), Pavetteae (6 sp.), Naucleae (5 sp.), Ixoreae (4 sp.), Aleisantheae (2 sp.), Mussaendeae ( $2 \mathrm{sp}$.), and Vanguerieae ( $2 \mathrm{sp}$.). The rest of the tribes, i.e., Augusteae, Coffeeae, Gardenieae, Knoxieae, and Morindeae, are represented by a single species. Minanga, Nabbabalayan and Sisim harbor the most species. Results show that 19 Philippine endemic species are thriving in the PPLS. Of these, four are threatened species; one is near threatened, three being least concern, two as data deficient, and the rest were not evaluated.
\end{abstract}

Keywords: Conservation, Peñablanca Protected Landscape and Seascape, purposive sampling, Rubiaceae, species richness

Abbreviations: CR: critically endangered; DD: data deficient; DENR: Department of Environment and Natural Resources; EN: endangered; LC: least concern; $m$ asl.: meter above sea level; NSMNP: Northern Sierra Madre Natural Park, PA: protected area; PLS: Protected Landscape and Seascape, sp./spp.: species; VU: vulnerable

\section{INTRODUCTION}

Peñablanca is a first-class municipality in the province of Cagayan, Philippines. The town is blessed with natural resources, such as rich forests, abundant biodiversity in its lakes and rivers, and vast fertile agricultural lands. Peñablanca Protected Landscape and Seascape (PPLS), formerly called Callao Cave National Park, is the largest protected area (PA) in Cagayan province in Northern Philippines. It is located on the border of Isabela province, contiguous with the Northern Sierra Madre Natural Park (NSMNP). This PA is well known for its numerous limestone formations found within its 300 cave systems, the most popular of which are Callao Cave and Sierra Cave. It is traversed by the Pinacanauan River, a major tributary of the Rio Grande de Cagayan (DENR 2016).

Surveys done in the area proved that Peñablanca PLS is home to a unique community of species of plants, such as the filmy ferns Hymenophyllum reinwardtii Bosch), and ground orchids (Cyrtosia sp.), and animals, such as the Philippine eagle Pithecophaga jefferyi), the Whiskered Pitta (Pitta kochi), and the Palanan Shrew Mouse (Archboldomys musseri). The PA covers the largest block of forest under conservation in the province. It comprises old-growth forest, secondary forest, and mossy forest and is ideal for studies on plant and animal diversity (DENR 2009). The Rubiaceae is a component of Peñablanca PLS, particularly in the secondary growth forest on the limestone karst substrates. In the Philippines, few studies on this forest type have been conducted (Tolentino et al. 2020). The presence of Rubiaceae species has been revealed in the limestone forests in the Philippines, particularly in Dinagat Island (Lillo et al. 2019), Eastern Samar (Ordas 2019), Rajah Sikatuna Protected Landscape, Bohol (Aureo 2020), Paranas, Samar Island Natural Park (Villanueva et al. 2021), Metropolitan Ilocos Norte Watershed Forest Reserve (Batuyong 2020). The high floral richness that has been recorded on this type of forest is still underestimated (Clements et al. 2006; Tolentino et al. 2020).

Rubiaceae is the fourth largest family of Angiosperms (Robbrecht 1988; Barbhuiya et al. 2014; Tobgay and Sridith 2019; Ly et al. 2020; Batuyong et al. 2021; Biag and Alejandro 2021) and exist as trees, shrubs, climbers, or herbs. They comprise 604 accepted genera (POWO 2021) and approximately 13,100 species (Delprete and Jardim 2012). Of the 535 species in about 80 genera found in the country, 443 species (83\%) are endemic (Banag 2017). The family has the highest number of indigenous species among Philippine eudicots with four endemic genera, i.e., Antherostele Bremek., Greeniopsis Merr., Kanapia Arriola 
\& Alejandro and Villaria Rolfe (Madulid 1991; Alejandro and Liede 2003; Alejandro et al. 2010; Arriola et al. 2016). There are numerous unresolved generic complexes, many undescribed genera, and several hundred undescribed species in this plant family (Robbrecht and Manen 2006; Alejandro 2007; Kainulainen et al. 2013). The need for further research on Rubiaceae is great.

Protected areas are the cornerstone of the global conservation strategies (Clerici et al. 2007; Munoz-Brenes et al. 2018; Geldmann et al. 2019; CBD 2020) and constitute a unique laboratory for research (Sinsin 2012). We do not want anonymous extinction to happen, i.e., species disappear before being formally named. To address one of the management programs of the PA focused on biodiversity protection and conservation, a floristic survey of the highly diverse Rubiaceae family as an initial step was conducted. This study specifically aimed to determine the species diversity of Rubiaceae in the Peñablanca PLS. Further, this study intended to determine which part of the PA these species are distributed. Lastly, it sought to determine which of these are Philippine endemic and give their corresponding conservation status.

\section{MATERIALS AND METHODS}

\section{Study area}

The survey was conducted at Penablanca PLS, the southernmost part of Cagayan province at $121^{\circ} 49^{\prime}$ to $122^{\circ} 13^{\prime}$ $\mathrm{E}$ and $17^{\circ} 32^{\prime}$ to $17^{\circ} 50^{\prime} \mathrm{N}$ covering seven barangays/districts, i.e., Aggugaddan, Cabasan, Nabbabalayan, San Roque, and Sisim on the western side and Mangga and Minanga on the eastern side. The boundaries of Peñablanca PLS are the municipality of Baggao, Cagayan, in the north; the Pacific Ocean in the east; the province of Isabela in the south and by Tuguegarao City and the municipality of Iguig, Cagayan, in the west (Figure 1). Peñablanca PLS has a total area of 103,801 ha of land and was declared a protected area under Proclamation No. 416 signed by then-President Fidel V. Ramos on June 29, 1994. The collection was particularly done in secondary-growth forests on limestone karst substrates covering an area of 7,000 ha. Profile of surveyed barangay is presented in Table 1 .
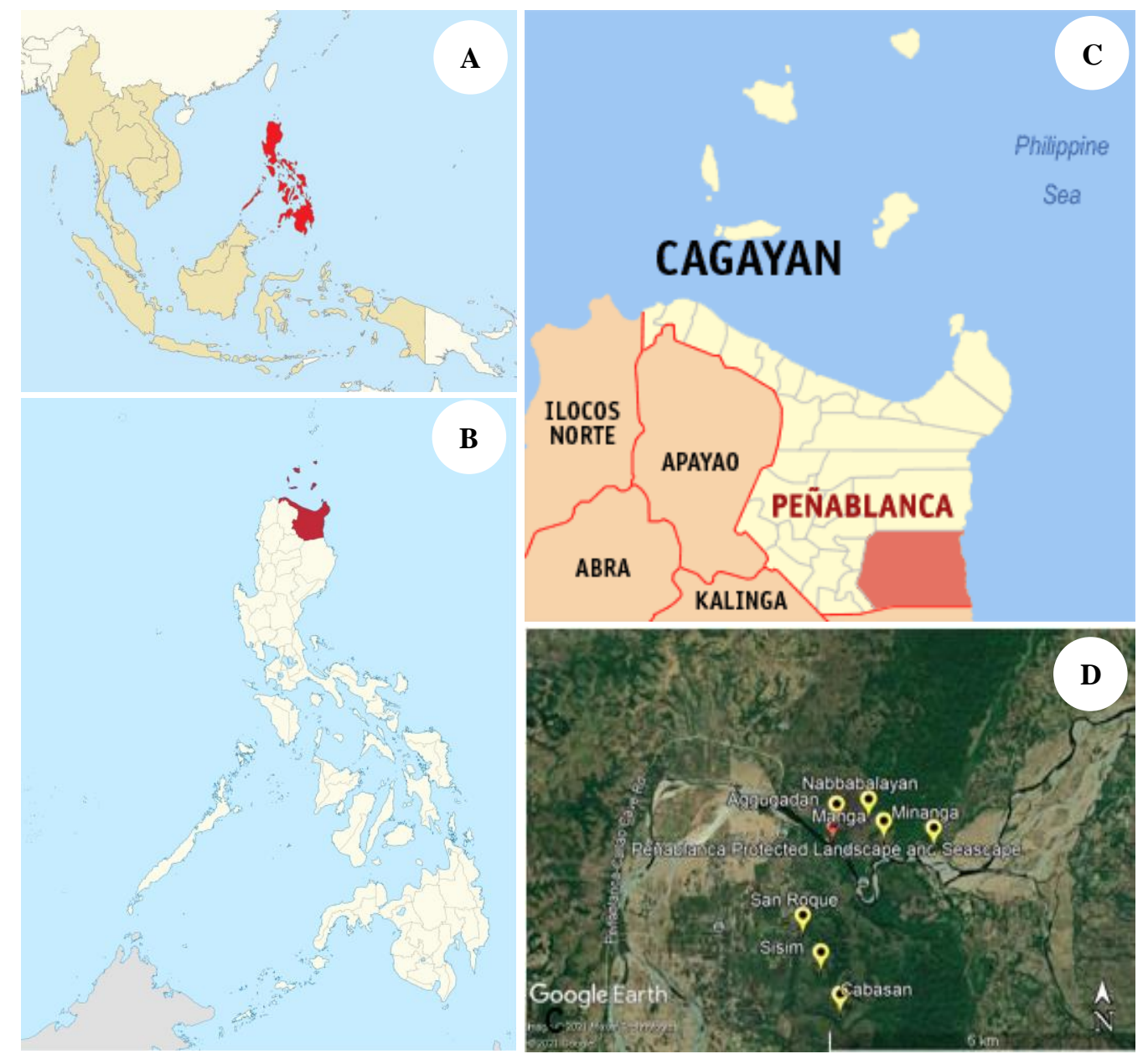

Figure 1. A. Map of South East Asia showing the Philippines, B. Map of the Philippines showing the location of Peñablanca, C. Map of Peñablanca showing the Peñablanca PLS D. Surveyed sites are secondary growth forests on limestone karst substrates and are marked yellow 
Table 1. Profile of the surveyed barangays covered by the Peñablanca Protected Landscape and Seascape, Philippines

\begin{tabular}{|c|c|c|c|c|c|c|}
\hline $\begin{array}{l}\text { Barangay/ } \\
\text { District }\end{array}$ & $\begin{array}{l}\text { Elevation } \\
\text { (m asl.) }\end{array}$ & $\begin{array}{c}\text { Slope } \\
\text { (DENR } \\
\text { 2016) }\end{array}$ & $\begin{array}{c}\text { Soil Type } \\
\text { (DENR } \\
\text { 2016) }\end{array}$ & $\begin{array}{c}\text { Climate } \\
\text { (Coronas 1920, } \\
\text { Kintanar 1984) }\end{array}$ & Coordinates & Threats \\
\hline Aggugadan & $88-110$ & UR & SSCR & Type III & $17^{\circ} 42^{\prime} 12^{\prime \prime} \mathrm{N}, 121^{\circ} 48^{\prime} 11^{\prime \prime} \mathrm{E}$ & Proximity to a tourist spot \\
\hline Cabasan & $60-98$ & UR & SSCR & Type III & $17^{\circ} 35^{\prime} 17^{\prime \prime} \mathrm{N}, 121^{\circ} 49^{\prime} 56^{\prime \prime} \mathrm{E}$ & None has been observed \\
\hline Nabbabalayan & 43-101 & UR & SSCR & Type III & $17^{\circ} 42^{\prime} 30.4^{\prime \prime} \mathrm{N}, 121^{\circ} 50^{\prime} 51.8^{\prime \prime} \mathrm{E}$ & None has been observed \\
\hline San Roque & 284-314 & UR & SSCR & Type III & $17^{\circ} 39^{\prime} 58^{\prime \prime} \mathrm{N}, 121^{\circ} 49^{\prime} 36 \mathrm{E}$ & None has been observed \\
\hline Sisim & $333-344$ & UR & SSCR & Type III & $17^{\circ} 38^{\prime} 18^{\prime \prime} \mathrm{N}, 121^{\circ} 49^{\prime} 30^{\prime \prime} \mathrm{E}$ & $\begin{array}{l}\text { Land conversion, } \\
\text { Slash-and-burn farming }\end{array}$ \\
\hline Mangga & $97-144$ & RM & UM & Type IV & $17^{\circ} 42^{\prime} 4^{\prime \prime N}, 121^{\circ} 51^{\prime} 37^{\prime \prime} \mathrm{E}$ & Land conversion \\
\hline Minanga & $111-171$ & $\mathrm{RM}$ & UM & Type IV & $17^{\circ} 42^{\prime} 50^{\prime \prime N}, 121^{\circ} 52^{\prime} 33^{\prime \prime} \mathrm{E}$ & $\begin{array}{l}\text { Slash-and-burn farming, } \\
\text { Timber poaching }\end{array}$ \\
\hline
\end{tabular}

Note: Slope (UR: Undulating to rolling, RM: Rolling to moderately steep), Soil type (SSCR: Sandy loam, silt loam, clay loam, and rocky land, UM: Undifferentiated mountain soil)

\section{Sampling, collection, and processing of specimens}

This botanical survey was conducted in three field expeditions. Two western barangays i.e. Aggugadan and Nabbabalayan were surveyed on September 19-23, 2016. Meanwhile, surveys were done in Cabasan, San Roque, Sisim, Mangga, and Minanga on February 18-22, 2017. Some of the collections lacked the reproductive parts, so we decided to revisit those areas on April 3-9, 2019. Many of these Rubiaceae species were having already flowers and fruits. Explorative inventory through purposive sampling was employed in the study. The collection was done along approximately $10 \mathrm{~m}$ adjacent to trails at the study sites (Ordas et al. 2019. These collections were pressed, dried, and mounted following standard procedures for herbarium vouchers. All specimens were deposited at the University of Santo Tomas Herbarium (USTH).

\section{Identification of plant materials}

Comprehensive morphological examinations of each Rubiaceae sample were carried out using a foldable magnifier and cordless Prepscope compound microscope to ensure that proper identification of the species is achieved. Character states presented for each species were based on Beentje (2016). Observation of herbarium specimens from local herbaria, such as the Philippine National Herbarium $(\mathrm{PNH})$, University of the Philippines Herbarium (PUH), University of Santo Tomas Herbarium (USTH), and Environmental Information Center Herbarium-Isabela State University, Cabagan (EICH-ISUC) was also done.

Further, we also compared our materials with images in the "Co's Digital Flora of the Philippines" (Pelser et al. 2011 onwards) and digital herbarium specimens available through Plants of the World Online (POWO 2021) (http://www.plantsoftheworldonline.org/) and Global Biodiversity Information Facility (GBIF) (https://www.gbif.org/). With these, most of the collected samples could be identified. Consultation of the World Checklist of Selected Plant Families (WCSP 2021), International Plant Names Index (IPNI 2021), and Plants of the World Online (POWO 2021) was done to provide the correct scientific name for each species.

Species endemicity, in this case, the Philippine endemic was determined using Co's Digital Flora of the Philippines (Pelser et al. 2011 onwards) and research papers on Rubiaceae, particularly published by the Thomasian
Angiosperm Phylogeny and Barcoding Group (TAPBG 2017, 2019). Meanwhile, the conservation status of these endemics was known using the IUCN Red List of Threatened Species 2021-1, DENR Administrative Order (DAO) 2017-11, and reference material by Sohmer and Davis (2007).

\section{RESULTS AND DISCUSSION}

\section{Diversity and distribution of Rubiaceae species in Peñablanca PLS}

Forty-two Rubiaceae species belonging to 19 genera and representing 13 tribes were determined in this study. Of the 42 species, 32 are the actual collections, and the remaining ten species are the previously known Rubiaceae recorded in the Peñablanca PLS. Four collections were not identified up to the species level due to the lack of reproductive parts. Five others have the said parts, but it's diverging from the characters of the different species under that genus; hence, they can be species new to science. The list of these species is given in Table 2. Among these species, 24 species (57\%) are shrubs, ten species (24\%) are herbs, seven species (17\%) are small trees, and one species (2\%) is a climber. This datum agrees with Watson et al. (1992), who stressed that the shrub habit is the most common in the family, but Rubiaceae can also be trees, lianas, and herbs. Twenty-nine species were identified as native to the Philippines, while four species are introduced. The most species-rich tribes are Spermacoceae (9 sp.), followed by Psychotrieae (7 sp.), Pavetteae (6 sp.), Naucleae (5 sp.), Ixoreae (4 sp.), Aleisantheae (2 sp.), Mussaendeae (2 sp.) and Vanguerieae (2 sp.). A single species represents the remaining tribes, including Augusteae, Coffeeae, Gardenieae, Knoxieae, and Morindeae. Psychotrieae (9 sp.) and Spermacoceae ( 8 sp.) are also the most specious tribes in NSMNP, as observed by Biag and Alejandro (2021). The genera include Coffea L., Greeniopsis Merr., Hedyotis L., Ixora L., Kanapia Arriola \& Alejandro, Knoxia L., Morinda L., Mussaenda Burm. ex L., Nauclea L., Neonauclea Merr., Oldenlandia L., Pavetta L., Psychotria L., Psydrax Gaertn., Spermacoce L., Tarenna Gaertn., Tarrenoidea Tirveng. \& Sastre, Uncaria Schreb. and Wendlandia Bartl. ex DC. 
Table 2. Checklist of Rubiaceae species in Peñablanca Protected Landscape and Seascape, Philippines

\begin{tabular}{|c|c|c|c|c|c|}
\hline Species & Habit & Distribution & Status & $\begin{array}{c}\text { Coordinates } \\
\text { Lat. }(\mathbf{N}), \text { Lon. }(\mathrm{E}) \\
\end{array}$ & Acc. No. \\
\hline \multicolumn{6}{|l|}{ Tribe Augusteae } \\
\hline \multirow[t]{3}{*}{ Wendlandia luzoniensis DC.* } & $\mathrm{T}$ & $\mathrm{N}$ & $\mathrm{N}$ & $17^{\circ} 41^{\prime} 47.6^{\prime \prime} 121^{\circ} 49^{\prime} 51.4^{\prime \prime}$ & USTH 016361 \\
\hline & & $\mathrm{Mi}$ & & $17^{\circ} 41.258^{\prime} 121^{\circ} 55.399^{\prime}$ & - \\
\hline & & $\mathrm{S}$ & & $17^{\circ} 40.430^{\prime} 121^{\circ} 51.797^{\prime}$ & - \\
\hline \multicolumn{6}{|l|}{ Tribe Aleisanthieae } \\
\hline Greeniopsis pubescens Merr.* & $\mathrm{T}$ & $\mathrm{N}$ & $\mathrm{N}$ & $17^{\circ} 41^{\prime} 41.8^{\prime \prime} 121^{\circ} 49^{\prime} 49.6 "$ & USTH- 016332 \\
\hline Greeniopsis multiflora (Elmer) Merr.*+ & $\mathrm{T}$ & $\mathrm{Mi}$ & $\mathrm{N}$ & - & \\
\hline \multicolumn{6}{|l|}{ Tribe Coffeae } \\
\hline Coffea arabica $\mathrm{L}$. & $\mathrm{S}$ & $\begin{array}{c}\text { SR } \\
\text { A }\end{array}$ & I & $\begin{array}{l}17^{\circ} 38.337^{\prime} 121^{\circ} 50.255^{\prime} \\
17^{\circ} 41^{\prime} 41.8^{\prime \prime} 121^{\circ} 49^{\prime} 49.6^{\prime \prime}\end{array}$ & USTH- 016331 \\
\hline \multicolumn{6}{|l|}{ Tribe Gardenieae } \\
\hline Tarennoidea wallichii (Hook.f.) Tirveng. \& Sastre & $\mathrm{S}$ & $\mathrm{S}$ & I & $17^{\circ} 38.285^{\prime} 121^{\circ} 50.400^{\prime}$ & USTH 016354 \\
\hline \multicolumn{6}{|l|}{ Tribe Ixoreae } \\
\hline Ixora auriculata Elmer*+ & $\mathrm{S}$ & - & $\mathrm{N}$ & - $\quad$ & - \\
\hline Ixora cumingiana $\mathrm{S}$. Vidal* & $\mathrm{S}$ & $\mathrm{N}$ & $\mathrm{N}$ & $17^{\circ} 41^{\prime} 42.3^{\prime \prime} 121^{\circ} 49^{\prime} 51.6^{\prime \prime}$ & USTH 016351 \\
\hline Ixora macrophylla Bartl. ex DC. & $\mathrm{S}$ & A & $\mathrm{N}$ & $17^{\circ} 42^{\prime} 18.1 " 121^{\circ} 49^{\prime} 10.5 "$ & USTH 016352 \\
\hline Ixora sp. & $\mathrm{S}$ & $\mathrm{S}$ & - & $17^{\circ} 38.285^{\prime} 121^{\circ} 50.400^{\prime}$ & USTH 016353 \\
\hline \multicolumn{6}{|l|}{ Tribe Knoxieae } \\
\hline Knoxia sumatrensis (Retz.) DC. ${ }^{+}$ & $\mathrm{H}$ & Mi & $\mathrm{N}$ & - & - \\
\hline \multicolumn{6}{|l|}{ Tribe Morindeae } \\
\hline Morinda citrifolia $\mathrm{L}$. & $S$ & $\mathrm{C}$ & $\mathrm{N}$ & $17^{\circ} 36.153^{\prime} 121^{\circ} 49.545^{\prime}$ & USTH 016355 \\
\hline \multicolumn{6}{|l|}{ Tribe Mussaendeae } \\
\hline Mussaenda philippica A. Rich var. philippica* & $S$ & $\begin{array}{l}\mathrm{N} \\
\mathrm{Mi}\end{array}$ & $\mathrm{N}$ & $\begin{array}{l}17^{\circ} 42 ’ 25.3 " 121^{\circ} 48^{\prime} 59.7^{\prime \prime} \\
17^{\circ} 41.191^{\prime} 121^{\circ} 55.3999^{\prime}\end{array}$ & USTH 016356 \\
\hline Mussaenda sp. & $\mathrm{S}$ & $\mathrm{C}$ & - & $17^{\circ} 36.129^{\prime} 121^{\circ} 49.377^{\prime}$ & USTH 016357 \\
\hline \multicolumn{6}{|l|}{ Tribe Naucleae } \\
\hline Neonauclea reticulata (Havil.) Merr. & $\mathrm{T}$ & $\begin{array}{c}\mathrm{Mi} \\
\mathrm{N}\end{array}$ & $\mathrm{N}$ & $\begin{array}{l}17^{\circ} 40.977^{\prime}, 121^{\circ} 53.760^{\prime} \\
17^{\circ} 38.285^{\prime} 121^{\circ} 50.401^{\prime}\end{array}$ & $\begin{array}{l}\text { USTH } 016358 \\
-\end{array}$ \\
\hline Neonauclea media (Havil.) Merr.**+ & $\mathrm{T}$ & $\begin{array}{l}\mathrm{SR} \\
\mathrm{M}\end{array}$ & $\mathrm{N}$ & $\begin{array}{l}17^{\circ} 38.328,121^{\circ} 50.153 \\
17^{\circ} 40.217,121^{\circ} 51.585\end{array}$ & $\begin{array}{l}- \\
-\end{array}$ \\
\hline Nauclea orientalis (L.) L. ${ }^{+}$ & $\mathrm{T}$ & - & $\mathrm{N}$ & - & - \\
\hline Nauclea sp. & $\mathrm{T}$ & $\mathrm{N}$ & - & - & - \\
\hline \multirow[t]{2}{*}{ Uncaria perrottetii (A. Rich.) Merr.* } & $\mathrm{C}$ & $\mathrm{Mi}$ & $\mathrm{N}$ & $17^{\circ} 41^{\prime} 41.8^{\prime \prime} 121^{\circ} 49^{\prime} 49.8^{\prime \prime}$ & USTH 016359 \\
\hline & & & & $17^{\circ} 41.140^{\prime} 121^{\circ} 55.397^{\prime}$ & USTH 016360 \\
\hline \multicolumn{6}{|l|}{ Tribe Psychotrieae } \\
\hline Psychotria luzoniensis (Cham. \& Schltdl.) Fern.-Vill.* & $\mathrm{S}$ & $\mathrm{C}$ & $\mathrm{N}$ & $17^{\circ} 36.153^{\prime} 121^{\circ} 49.377^{\prime}$ & USTH 016342 \\
\hline Psychotria gitingensis Elmer* & $\mathrm{S}$ & $\mathrm{N}$ & $\mathrm{N}$ & $17^{\circ} 41^{\prime} 47.6 " 121^{\circ} 49^{\prime} 51.4^{\prime \prime}$ & USTH 016343 \\
\hline Psychotria frakei Sohmer \& A.P. Davis* & $\mathrm{S}$ & $\mathrm{N}$ & $\mathrm{N}$ & $17^{\circ} 42 ’ 25.3 " 121^{\circ} 48^{\prime} 59.7 "$ & USTH 016344 \\
\hline Psychotria nitens (Merr.) Merr.* & $\mathrm{S}$ & $\mathrm{S}$ & $\mathrm{N}$ & $17^{\circ} 38.276^{\prime} 121^{\circ} 50.390^{\prime}$ & USTH 016345 \\
\hline Psychotria sp. & $\mathrm{S}$ & SR & $\mathrm{N}$ & $17^{\circ} 38.337^{\prime} 121^{\circ} 50.280^{\prime}$ & USTH 016346 \\
\hline Psychotria diffusa Merr. var. diffusa*+ & $\mathrm{S}$ & - & - & - & - \\
\hline Psychotria weberi Merr.*+ & $\mathrm{S}$ & Mi & $\mathrm{N}$ & - & - \\
\hline \multicolumn{6}{|l|}{ Tribe Pavetteae } \\
\hline Pavetta barnesii Elmer ex Merr. & $\mathrm{S}$ & $\mathrm{Mi}$ & $\mathrm{N}$ & $17^{\circ} 41.127^{\prime} 121^{\circ} 55.391^{\prime}$ & USTH 016347 \\
\hline Pavetta sp. & $\mathrm{S}$ & $\mathrm{Mi}$ & - & $17^{\circ} 41.135,121^{\circ} 55.397$ & USTH 016348 \\
\hline Pavetta indica $\mathrm{L}^{+}$ & $\mathrm{S}$ & $\mathrm{N}$ & $\mathrm{I}$ & $17^{\circ} 41^{\prime} 45.4 " 121^{\circ} 49^{\prime} 52.2 "$ & - \\
\hline Tarenna elongata Merr.* & $\mathrm{S}$ & $\mathrm{N}$ & $\mathrm{N}$ & $17^{\circ} 411^{\prime} 43.6 " 121^{\circ} 499^{\prime} 51.9 "$ & USTH 016349 \\
\hline Tarenna sp. & $\mathrm{S}$ & $\mathrm{S}$ & - & $17^{\circ} 38.285^{\prime} 121^{\circ} 50.400^{\prime}$ & USTH 016350 \\
\hline Tarenna cumingiana $(\mathrm{S}$. Vidal) Elmer*+ & $\mathrm{S}$ & $\mathrm{Mi}$ & $\mathrm{N}$ & $-\quad 0.20012100 .600$ & - \\
\hline \multicolumn{6}{|l|}{ Tribe Spermacoceae } \\
\hline Hedyotis bambusetorum Merr.* & $\mathrm{H}$ & Mi & $\mathrm{N}$ & $17^{\circ} 40.406^{\prime} 121^{\circ} 51.793$ & USTH 016333 \\
\hline Hedyotis simplex Merr.* & $\mathrm{H}$ & $\mathrm{Mi}$ & $\mathrm{N}$ & $17^{\circ} 40.720^{\prime} 121^{\circ} 53.193^{\prime}$ & USTH 016334 \\
\hline Hedyotis sp.1 & $\mathrm{H}$ & $\mathrm{Mi}$ & - & $17^{\circ} 411^{\prime} 45.4 " 121^{\circ} 49^{\prime} 52.2 "$ & USTH 016335 \\
\hline Hedyotis sp. 2 & $\mathrm{H}$ & $\mathrm{Mi}$ & - & $17^{\circ} 40.733^{\prime} 121^{\circ} 54.127^{\prime}$ & USTH 016336 \\
\hline Spermacoce alata Aubl. & $\mathrm{H}$ & $\mathrm{M}$ & $\mathrm{I}$ & $17^{\circ} 40.404,121^{\circ} 51.793$ ' & USTH 016337 \\
\hline Spermacoce ocymoides Burm. f. & $\mathrm{H}$ & $\mathrm{Mi}$ & $\mathrm{N}$ & $17^{\circ} 40.731^{\prime} 121^{\circ} 54.126^{\prime}$ & USTH 016338 \\
\hline Spermacoce remota Lam. & $\mathrm{H}$ & $\mathrm{Mi}$ & $\mathrm{N}$ & $17^{\circ} 40.725^{\prime} 121^{\circ} 54.190^{\prime}$ & USTH 016339 \\
\hline Spermacoce sp. & $\mathrm{H}$ & $\mathrm{Mi}$ & & $17^{\circ} 40.408^{\prime} 121^{\circ} 51.703$ & USTH 016340 \\
\hline Oldenlandia corymbosa $\mathrm{L}$. & $\mathrm{H}$ & $\mathrm{Mi}$ & $\mathrm{N}$ & $17^{\circ} 40.404,121^{\circ} 51.793$, & USTH 016341 \\
\hline Tribe Vanguerieae & & & & & \\
\hline Kanapia monstrosum (A. Rich.) Arriola \& Alejandro*+ & $\mathrm{S}$ & $\mathrm{N}$ & $\mathrm{N}$ & $17^{\circ} 41^{\prime} 43.3 " 121^{\circ} 49^{\prime} 51.5 "$ & USTH 016330 \\
\hline $\begin{array}{l}\text { Psydrax gynochthodes (Baill.) Arriola, Yayen \& } \\
\text { Alejandro }\end{array}$ & $\mathrm{S}$ & $\mathrm{N}$ & $\mathrm{N}$ & - & - \\
\hline
\end{tabular}

Note: Habitus (T: Tree, S: Shrub, H: Herb, C: Climber), distribution (A: Aggugaddan, C: Cabasan, M: Mangga, Mi: Minanga, N: Nabbabalayan, S: Sisim, SR: San Roque), status (N: Native, I: Introduced). Names with ${ }^{*}$ and ${ }^{+}$are Philippine endemics and the previously recorded Rubiaceae species in the Peñablanca PLS, respectively. 
It is also worth mentioning that Coffea arabica L., a species not native to the Philippines, was found in the middle part of the limestone forest of barangays San Roque and Aggugaddan. According to the tour guides, individuals of this species were grown by the local people for human consumption. Nineteen Philippine endemic species (Table 2, Figure 2) were documented in this study. This number of endemics supports the fact that Southeast Asia's karsts support a very high level of endemic species (Clements et al. 2006; Schilthuizen et al. 2005; Latinne et al. 2011; Tolentino et al. 2020). In a study on the tower karst limestone formation in Selangor, Malaysia (Kiew 2014), a total of 269 species of vascular plants were recorded, of which 51 are endemic. In the Philippines, Calumpong (2014) recorded 23 endemics out of the 61 species collected in Baladingan, Ticao Island.

The species were collected at the secondary-growth forests on limestone karst substrates at low elevations ranging from 43-344 $\mathrm{m}$ asl. Ly et al. (2020) cited that Rubiaceae are especially abundant in lowland humid tropical forests. They further added that this family is the most species-rich of the woody plant families. A checklist by Ordas et al. (2019) also proved that species belonging to Rubiaceae could also be found in forests over the limestone of Eastern Samar, Visayas.

Among the surveyed barangays, Minanga harbored the most genera and species. This number of species is substantial and can be added to the previous collections (4 sp.), giving 18 species in the barangay mentioned above (Table 3). One factor that might explain this is its remoteness, about $6 \mathrm{~km}$ from human settlements; thus, it is less likely to be exploited than humans can easily access. This coincides with the citation of Carver (2020) about the Madagascar forest, which was long protected by its remoteness, but data say that its biodiversity is now threatened. According to Carver (2020), between 1996 and 2006, Tsaratanana Reserve in Northern Madagascar losts only about $0.1 \%$ of its forest cover to deforestation per year. From 2006 to 2016, however, the level of deforestation increased to about $0.5 \%$ per year and the rate has been $1.3 \%$ or higher every year since 2016 . Construction of roads in remote rural areas improves livelihoods but poses negative environmental impacts such as increased deforestation (Barber et al. 2014; Charlery et al. 2016). Also, the presence of large and sharp in Minanga hinders any person from exploring the area. Though, it is not completely spared from anthropogenic influences amidst its distance, as evident by marks of timber poaching and slash-and-burn agriculture. The next species and the genera-rich area is Nabbabalayan, which is inaccessible via land transportation. Previous records show that one species thrives in this site, and adding up to the actual number of collections which is ten species, would give a total of 11 species all in all in this barangay. People cannot just explore the area unless they ride on a motorized boat. This can be a means of protecting the biodiversity of the area. Although barangay Sisim also experiences human disturbances like slash-and-burn farming to cultivate preferred fruiting trees and crops as directly observed by the researchers and was further explained by a staff of the DENR, the area still ranked third in terms of the number of genera and species. Through shifting cultivation, the plants affected by the slash-and-burn farming are allowed to regrow after growing the preferred fruit-bearing trees and crops. For the rest of the collection sites, less than five genera and species were recorded. It has to be noted that there were previously recorded species listed in Table 2 with no specific collection sites. Literature just cited the general information that these species were collected in the Penablanca PLS.

According to Watson et al. (1992), Rubiaceae are known to tolerate a broad array of environmental conditions such as soil types, altitudes, community structures and do not specialize in one specific habitat type. This plant family is abundant, diverse, and well represented in all tropical vegetation layers (Delprete and Jardim 2012). Very few researches have been conducted correlating species richness of Rubiaceae with environmental conditions. A study by Tobgay and Sridith (2019) suggests that while the Rubiaceae species with a narrow distribution range were found concentrated at the lower altitude exhibiting endemic nature, the herbaceous species exhibiting maximum distribution range were dominant at the higher altitudinal range.

\section{Conservation status of endemic species}

Of the 19 endemic species thriving in the Peñablanca PLS (Table 4), four are threatened species, with one Critically Endangered (CR), one Endangered (EN), and two Vulnerable (VU) species. In addition, One is near threatened (NT), three being least concern (LC), two as data deficient (DD), and the rest were not evaluated (NE). Though the researchers did not assess the conservation status, those threatened florae were observed as a single individual in the study sites. Species under the category DD were evaluated as such due to the limited distributional data and lack of information on population size, trends, or threats to the species in the Philippines. The PA hosts one genus endemic to the Philippines, the Greeniopsis. Since endemic species are particularly sensitive to climate change, an understanding of climatic and ecological requirements and distribution constraints of endemic species is very crucial in developing conservation strategies that are robust to future climate changes (Ohlemu“ller et al. 2008; Fløjgaard et al. 2010; Banag et al. 2015, Case et al. 2015; Sintayehu 2018; Dagnino et al. 2020; Manes et al. 2021). Ixora is one of the genera that can be significantly affected. Banag et al. (2015) have proven this in their study focused on Ixora affected by climate change. Ixora auriculata and Ixora bartlingii are vulnerable to climate change and will eventually lead to shrinkage or shift in geographical range. Both species will likely shift their geographic distributions southwards under predicted levels of climate change. The most frequently reported changes in plant ecology in response to climate change are changes in species' geographical distributions, which are likely to be preceded by a change in plant growth (Morecroft and Keith 2020). This climate change-related phenomenon will be 
evident in Luzon, Philippines, because of the increasing extreme rainfall in the coming years, as PAGASA (2018) projected and exposure to tropical cyclones. In Cagayan, where Penablanca is found, an increase in the seasonal rainfall for December, January, and February 2020 has been observed, with a value of $304 \mathrm{~mm}$ compared to the observed baseline (1971-2000) for the same months, which is $284.4 \mathrm{~mm}$. It is projected that an additional increase of $14.6 \%$ of rainfall for these months in Cagayan will be noticeable in 2050 (PAGASA 2011, 2018). Luzon's loss of suitable areas will force the Ixora species to shift to potential zones towards the western Visayas and Mindanao (Banag et al. 2015).

Climate change projections by PAGASA (2011) for Cagayan Province indicate a temperature increase of 0.8 to $1.0^{\circ} \mathrm{C}$ in 2020 and 1.8 to $2.2^{\circ} \mathrm{C}$ in 2050 , with dry months becoming drier and wet months wetter. The recorded temperature $\left(30^{\circ} \mathrm{C} \&\right.$ above $)$ for the province this 2021 (PAGASA 2021) surpassed the projected temperature in $2020\left(25.3^{\circ} \mathrm{C}\right)$. Continuous warming will be experienced in the future. According to PAGASA (2018), the country's average mean temperature could increase by as much as $0.9^{\circ} \mathrm{C}-1.9^{\circ} \mathrm{C}$ and $1.2^{\circ} \mathrm{C}-2.3^{\circ} \mathrm{C}$ in the mid-21st century (2036-2065). The temperature and rainfall changes will greatly impact agriculture, forestry, water resources, fisheries and marine resources, human settlements, biodiversity, and ecosystems in general. In biodiversity, for instance, filmy ferns like Hymenophyllum reinwardtii, a flora of the Penablanca PLS, will be affected by the increase in temperature. Being an indicator of super moist soil and wet places such as stream banks and waterfalls will, likewise, migrate up the mountain slopes along watercourses, terminating their upward migration to the vicinity of headwaters. Once these headwaters dry up, it will signal the start of their local extinction (DENR 2016).
All these environmental changes provide a grave threat to the Peñablanca PLS.

In a vulnerability assessment study (DENR 2016) conducted in the Peñablanca PLS, 109 plants were vulnerable to climate change, of which nine species belong to the family Rubiaceae. These are the species under the Philippine Penablanca Sustainable Reforestation Project (PPSRP) reforestation and enhancement. The rubiaceous species are Canthium monstruosum Merr. now Kanapia monstrosa (A. Rich.) Arriola \& Alejandro, Nauclea orientalis (L.) L., Neonauclea media Merr., Neonauclea reticulata Merr., Pavetta indica L., Psychotria gitingensis Elmer, Psychotria luzoniensis Fern.-Vill., Tarenna cumingiana Elmer, and Wendlandia luzoniensis DC. var. membranifolia (Elmer) Cowan. All of which were assessed to be moderately sensitive to climate change. Aside from the typhoons that occur every year, other hazards that provide additional threats to the Peñablanca PLS include flooding and rain-induced landslides. Peñablanca PLS is further ravaged by deforestation due to timber poaching, slash-and-burn farming, and conversion of forests into agricultural lands. In November 2020, the worst massive flooding was experienced in Cagayan province, particularly in Tuguegarao City, and what caused it is a confluence of factors. According to the PPLS Management Plan (2016), this flooding problem in the province is largely influenced by Peñablanca PLS because the rivers draining to the flood-prone areas come from the PA. Therefore, the vegetative cover of Peñablanca PLS greatly determines the degree of flooding in Cagayan. If areas are flooded, this can be attributed to the declining vegetation of the PA. Botanical surveys in the PA are urgent as many species await discovery and proper identification before becoming prey to extinction.

Table 4. List of endemic species and their conservation status

\begin{tabular}{|c|c|c|}
\hline Species & Status & References \\
\hline Wendlandia luzoniensis DC. & $\mathrm{NE}$ & - \\
\hline Greeniopsis pubescens Merr. & $\mathrm{CR}$ & DAO 2017-11 \\
\hline Greeniopsis multiflora (Elmer) Merr. & $\mathrm{LC}$ & IUCN 2021-1 \\
\hline Ixora auriculata Elmer & $\mathrm{NE}$ & - \\
\hline Ixora cumingiana $\mathrm{S}$. Vidal & NE & - \\
\hline Mussaenda philippica A. Rich var. philippica & $\mathrm{LC}$ & IUCN 2021-1 \\
\hline Neonauclea media (Havil.) Merr. & $\mathrm{NE}$ & - \\
\hline Uncaria perrottetii (A. Rich.) Merr. & NE & - \\
\hline Psychotria luzoniensis (Cham. \& Schltdl.) Ferm.-Vill. & $\mathrm{LC}$ & Sohmer and Davis (2007) \\
\hline Psychotria gitingensis Elmer & DD & - \\
\hline Psychotria frakei Sohmer \& A.P. Davis & EN & Sohmer and Davis (2007) \\
\hline Psychotria nitens (Merr.) Merr. & DD & - \\
\hline Psychotria diffusa Merr. var. diffusa & NT & Sohmer and Davis (2007) \\
\hline Psychotria weberi Merr. & VU & IUCN 2021-1 \\
\hline Tarenna elongata Merr. & NE & - \\
\hline Tarenna cumingiana (S. Vidal) Elmer & $\mathrm{NE}$ & - \\
\hline Hedyotis bambusetorum Merr. & VU & DAO 2017-11 \\
\hline Hedyotis simplex Merr. & NE & - \\
\hline Kanapia monstrosa (A. Rich.) Arriola \& Alejandro & NE & _ \\
\hline
\end{tabular}

Note: NE: Not Evaluated, DD: Data Deficient, OT: Other Threatened Species, LC: Least Concern V: Vulnerable, EN:Endangered, CR: Critically Endangered 


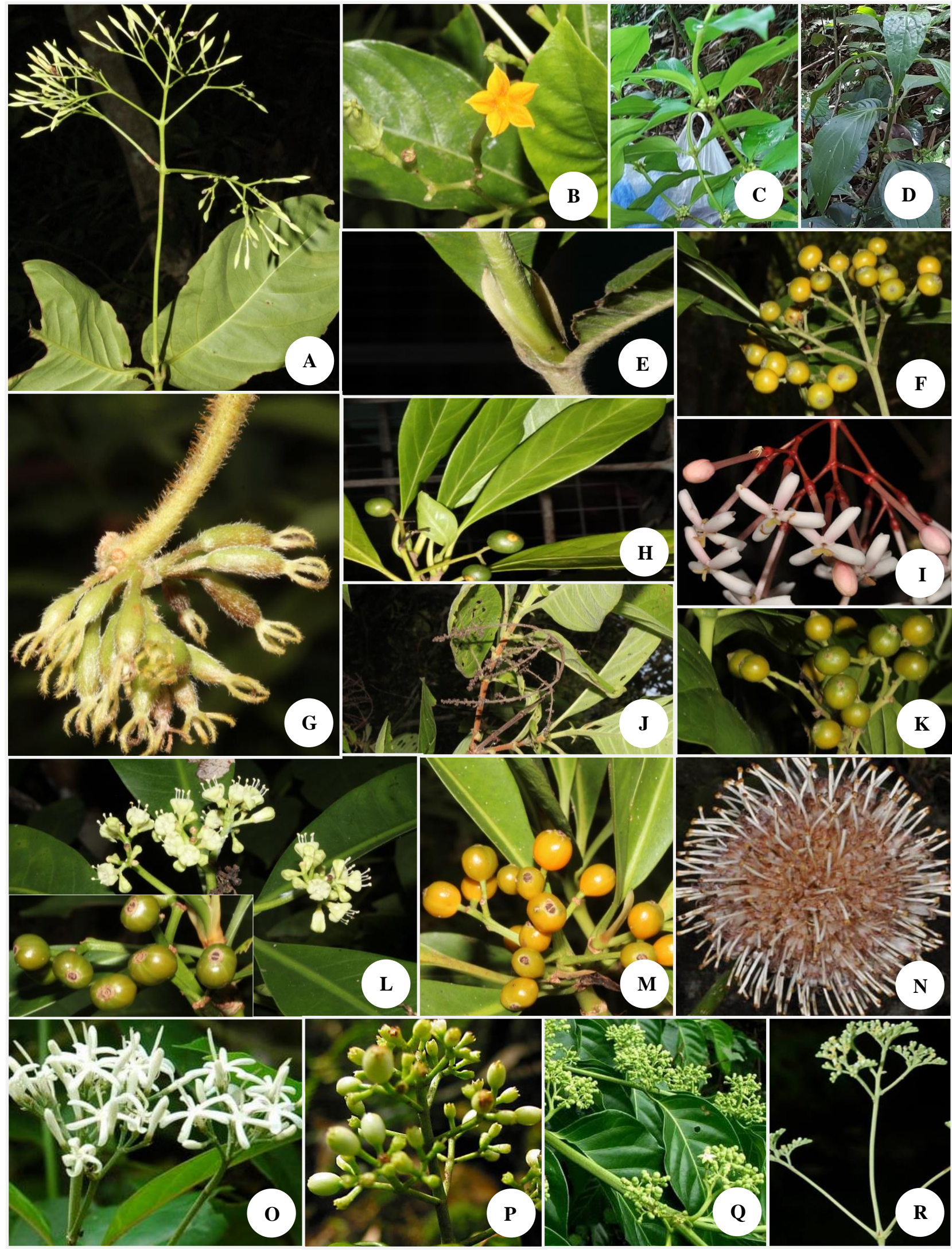

Figure 2. The endemic species recorded in Peñablanca PLS. A. Ixora cumingiana, B. Mussaenda philippica var. philippica, C. Hedyotis simplex, D. Hedyotis bambusetorum, E. Greeniopsis pubescens, F. Psychotria gitingensis, G. Uncaria perrottetii, H. Tarenna elongata, I. Ixora cumingiana, J. Wendlandia luzoniensis, K. Psychotria frakei ,L. Psychotria luzoniensis, M. Psychotria nitens, N. Neonauclea media, O. Tarenna cumingiana, P. Psychotria diffusa, Q. Kanapia monstrosa, R. Greeniopsis multiflora. Photos taken by R. Biag. Photos of the previously recorded species in the area ( I, N, O, P, Q and R) were obtained from the Co's Digital Flora of the Philippines (Pelser et al 2011 onwards). 
In conclusion, the Peñablanca PLS harbors 42 species of Rubiaceae belonging to 19 genera and representing 13 tribes. The most species-rich tribes are Spermacoceae $(9$ sp.), followed by Psychotrieae (7 sp.), Pavetteae (6 sp.), Naucleae (5 sp.), Ixoreae (4 sp.), Aleisantheae (2 sp.), Mussaendeae (2 sp.), and Vanguerieae (2 sp.). The rest of the tribes, i.e., Augusteae, Coffeeae, Gardenieae, Knoxieae, and Morindeae, are represented by a single species. Minanga, Nabbabalayan, and Sisim gave the highest number of species with 14,10 , and 5, respectively. Less than 5 species were recorded for Aggugadan, Cabasan, Manga, and San Roque. Of the total number, 19 species are endemic to the Philippines. It is worth mentioning that four of these species are threatened with one $\mathrm{CR}$, one $\mathrm{EN}$, and two VU species. Noteworthy is the presence of one NT, three LC, and two DD species. The rest, however, were not evaluated.

The Department of Environment and Natural Resources, through the Protected Area Management Board (PAMB), should establish a partnership with state colleges and universities to better monitor and assess its biodiversity. The same governing body, the DENR, and the local government of Peñablanca should allocate funds for the management mentioned above program to encourage more researchers to engage in environmental protection and biodiversity conservation activities. Publication of the researches conducted is also encouraged. Development and dissemination of Instruction, Education, and Communication (IEC) materials of the species could be carried out to develop people's awareness of these species particulary the endemic ones. The identified threatened species in this botanical survey urgently need our attention. As a response, regular monitoring should be done, but there should be a creation first of the map bearing the distribution of these species under threat. This could be a great step that could save them from the verge of extinction.

\section{ACKNOWLEDGEMENTS}

We thank the following herbaria: PNH, USTH, CAHUP, and EICH-ISUC, for access to their herbarium collections, and $\mathrm{K}, \mathrm{A}, \mathrm{NY}, \mathrm{L}, \mathrm{BM}, \mathrm{GH}$, and US for access to digital images. The first author would like to thank the Commission on Higher Education for the Scholarship Grant, Philippines. Acknowledgment is given to the Department of Environment and Natural Resources, Region 02, for granting the gratuitous permit that allowed fieldwork in the Penablanca PLS.

\section{REFERENCES}

Alejandro GJD, Liede S. 2003. The Philippine Rubiaceae Genera: Updated synopsis in INTKEY databases of the DELTA system. Blumea 48: 261-277. DOI: 10.3767/000651903X674964

Alejandro GJD. 2007. The current status of the Philippine Rubiaceae. Philipp J Syst Biol 1(1): 47-60. DOI: 10.3860/pjsb.v1i1.908

Alejandro GJD, Meve U, Uy M, Mouly A, Thiv M, Liede-Schumann S. 2010. Molecular support of the classification of Greeniopsis Merr. in
Aleisanthieae (Rubiaceae), with a revision of the genus. Taxon 59(5): 1547-1564. DOI: 10.2307/20774048

Arriola AH, Paraguison LD, Alejandro GJD. 2016. Kanapia (Vanguerieae): A new endemic genus of Philippine Rubiaceae. Plant Syst Evol 302: 911-920. DOI: 10.1007/s00606-016-1307-5

Aureo W, Sarnowski M, Reyes T, Jose R. 2020. Diversity and composition of plant species in the forest over limestone of Rajah Sikatuna Protected Landscape, Bohol, Philippines. Biodivers Data J 8(142): 55790. DOI:10.3897/BDJ.8.e55790

Banag CI, Alejandro GJD, Thrippleton T, Reineking B, Liede-Schumann S. 2015. Bioclimatic niches of selected endemic Ixora species on the Philippines: Predicting habitat suitability due to climate change. Plant Ecol 1325-1340. DOI: 10.1007/s11258-015-0512-6

Banag CI, Mouly A, Alejandro GJD, Bremer B, Meve U, Grimm G, Liede-Schumman S. 2017. Ixora (Rubiaceae) on the Philippinescrossroad or cradle?. BMC Evol Biol 17: 131. DOI: 10.1186/s12862017-0974-3

Barber CP, Cochrane MA, Souza CM, Laurance WF. 2014. Roads, deforestation, and the mitigating effect of protected areas in the Amazon. Biol Conserv 177: 203-209. DOI:10.1016/j.biocon.2014.07.004

Barbhuiya HA, Dutta BK, Das AK, Baishya AK. 2014. The Family Rubiaceae in Southern Assam with special reference to endemic and rediscovered plant taxa. J Threat Taxa 6(4): 5649-5659. DOI: 10.11609/JoTT.o3117.5649-59

Batuyong MAR, Calaramo MA, Alejandro GJD.2020. A checklist and conservation status of vascular plants in the Limestone forest of Metropolitan

Ilocos Norte Watershed Forest Reserve, Northwestern Luzon, Philippines. Biodiversitas 21: 3969-3981. DOI: 10.13057/biodiv/d21090

Batuyong MAR, Calaramo MA, Alejandro GJD. 2021. Diversity of Rubiaceae in Ilocos Norte, Northwestern Luzon, Philippines: A preliminary checklist, their distribution, and conservation status. Philipp J Sci 150: 487-502.

Beentje H. 2016. The Kew Plant Glossary: An Illustrated Dictionary of Plant Terms. Royal Botanic Gardens Kew, Richmond.

Biag R, Alejandro GJD. 2021. Rubiaceae flora of Northern Sierra Madre Natural Park, Isabela, Philippines: species richness, distribution, and conservation status. Philipp J Sci 150 (3): 909-923.

Calumpong HP. 2014. The flora of the limestone forest of Baladingan, Ticao Island, Philippines.EM Intl. Spec Issue-2014:11-23.

Carver E. 2020. A Madagascar forest long protected by its remoteness is now threatened by it. Mongabay Series: Conservation in Madagascar, Forest Trackers.

Case MJ, Lawler JJ, Tomasevic JA. 2015. Relative sensitivity to climate change of species in Northwestern North America. Biol Conserv 18: 127-133. DOI: 10.1016/j.biocon.2015.04.013

Charlery L, Nielsen MR, Meilby H, Smith-Hall C. 2016. Effects of new roads on environmental resource use in the Central Himalaya. Sustainability 8(4): 363. DOI:10.3390/su8040363

Clements R, Sodhi NS, Schilthuizen M, Ng PKL. 2006. Limestone karsts of Southeast Asia: Imperiled arks of biodiversity. BioScience 56(9):733. DOI: 10.1641/0006-3568(2006)56[733:lkosai]2.0.co;2

Clerici N, Bodini A, Eva H, Grégoire JM, Dulieu D, Paolini, C. 2007. Increased isolation of two biosphere reserves and surrounding protected areas (WAP ecological complex, West Africa). J Nat Conserv 15: 26-40. DOI: 10.1016/j.jnc.2006.08.003

Coronas J. 1920. The climate and weather of the Philippines, 1903-1918. Manila Observatory, Bureau of Philippines, Manila.

Convention on Biological Diversity [CBD]. 2020. Protected areas - an overview. https://www.cbd.int. [January 16 2021].

Dagnino D, Guerrina M, Minuto L, Mariotti MG, Medail F, Casazza G. 2020. Climate change and the future of endemic flora in the South Western Alps: Relationship between niche properties and extinction risk. Reg Environ Change 20: 121. DOI: 10.1007/s10113-020-017084

Delprete P, Jardim J. 2012. Systematics, taxonomy, and floristics of Brazilian Rubiaceae: An overview about the current status and future challenges. Rodriguesia 63(1): 101-128. DOI: 10.1590/S217578602012000100009

Department of Environment and Natural Resources [DENR]. 2009. Ecological Profile of Penablanca Protected Landscape and Seascape. 
Department of Environment and Natural Resources II [DENR]. 2016. Penablanca Protected Landscape and Seascape Management Plan. Strengthening climate change resilience through improved watershed and coastal resources management in protected areas.

Department of Environment and Natural Resources Administrative Order (DAO 2017). 2017. Updated national list of threatened Philippine plants and their categories. DAO 2017-11 https://server2.denr.gov.ph/uploads/ rmdd/dao-2017-11.pdf

Fløjgaard C, Normand S, Skov F, Svenning JC. 2010. Deconstructing the mammal species richness pattern in Europe towards an understanding of the relative importance of climate, biogeographic history, habitat heterogeneity, and humans. Glob Ecol Biogeogr 20: 218-230. DOI: 10.1111/j.1466-8238.2010.00604.x

GBIF. 1999-onwards. Global Biodiversity Information Facility. https: //www.gbif.org. [January 10 2021].

Geldmann J, Manica A, Burgess N, Coad L, Balmford A. 2019. A globallevel assessment of the effectiveness of protected areas at resisting anthropogenic pressures. Proc Natl Acad Sci USA 116(46): 2320923215. DOI: $10.1073 /$ pnas.1908221116

IPNI. 2021. International Plant Names Index. http: //www.ipni.org. [January 10 2021].

IUCN 2021. The IUCN Red List of Threatened Species. Version 2021-1. https://www.iucnredlist.org. [January 10 2021].

Kainulainen K, Razafimandimbison S, Bremer B. 2013. Phylogenetic relationships and new tribal delimitations in subfamily Ixoroideae. Bot J Linn Soc 173: 387-406. DOI: 10.1111/boj.12038

Kiew R. 2014. Checklist of vascular plants from Batu Caves, Selangor, Malaysia. Check List 10(6):1420-1429. DOI: 10.15560/10.6.1420

Kintanar R. 1984. Climate of the Philippines. PAGASA. bagong.pagasa.dost.gov.ph [January 10 2021].

Latinne A, Waengsothorn S, Herbreteau V, Michau J.R, Baillarguet CIDe. 2011. Thai limestone karsts: An impending biodiversity crisis. Int Conf Environ Support-Ing Food Energy Secure: Crisis Opportunity(March):176-187.

Lillo EP, Fernando ES, Lillo MJR. 2019. Plant diversity and structure of forest habitat types on Dinagat Island, Philippines. J Asia-Pacific Biodivers 12(1):83-105. DOI: 10.1016/j.japb.2018.07.003

Ly SN, Garavito A, De Block P, Asselman P, Guyeux C, Charr J-C, Janssens S, Mouly Arnaud, Hamon P, Guyot R. 2020. Chloroplast genomes of Rubiaceae: Comparative genomics and molecular phylogeny in subfamily Ixoroideae. PLoS One 15(4): e0232295. DOI: 10.1371/journal.pone.0232295

Madulid DA. 1991. The endemic genera of flowering plants in the Philippines. Acta Manilana 39: 47-58.

Manes S, Costello M, Beckett H, Debnath A, Devenish-Nelson E, Grey KA, Jenkins R, Khan T, Kiessling W, Krause C, Maharaj S, Midgley G, Price J, Talukdar G, Vale M. 2021. Endemism increases climate change risk in areas of global biodiversity importance. Biol Consery 257. DOI: 10.1016/j.biocon.2021.109070

Morecroft MD, Keith S. 2020. Plant Ecology as an Indicator of Climate and Global Change. https://www.climate-policy-watcher.org/earthclimate/plant-ecology-as-an-indicator-of-climate-and-globalchange.html

Munoz-Brenes C, Jones KW, Schlesinger P, Robalino J, Vierling L. 2018 The impact of protected area governance and management capacity on ecosystem function in Central America. PloS One 13(10): e0205964. DOI: 10.1371/journal.pone.0205964

Ohlemu"ller R, Anderson BJ, Arau'jo MB, Butchart SHM, Kudrna O, Ridgely RS, Thomas CD. 2008. The coincidence of climatic and species rarity: High risk to small-range species from climate change. Biol Lett 4: 568-572. DOI: 10.1098/rsbl.2008.0097
Ordas JAD, Pinarok NAA, Romeroso RB, Alejandro GJD, Banag-Moran CI. 2019. A checklist of Rubiaceae species from Eastern Samar, Visayas, Philippines. Check List 15(2): 295-312. DOI: 10.15560/15.2.295

PAGASA. 2011. Available at: http: //kidlat.pagasa.dost.gov.ph/cab/climate_change/ [January 5 2021].

PAGASA. 2018. Observed and Projected Climate Change in the Philippines. Philippine Atmospheric, Geophysical, and Astronomical Services Administration, Quezon City, Philippines. [January 5 2021].

PAGASA 2021. Climate Review. Philippine Atmospheric, Geophysical, and Astronomical Services Administration, Quezon City, Philippines. [April 21 2021]

Pelser P, Barcelona J, Nickrent D. 2011 and onwards. Co's Digital Flora of the Philippines. http: //www.philippineplants.org. [January 5 2021].

POWO. 2021. Plants of the World Online. Facilitated by the Royal Botanic Gardens, Kew. Published on the Internet; http: //www.plantsoftheworldonline.org/. [January 10 2021].

Robbrecht E. 1988. Tropical woody Rubiaceae. Characteristic Features and Progressions. Contributions to a New Subfamilial Classification Opera Bot Belg 1: 1-271. DOI: 10.2307/4110534

Robbrecht E, Manen JF. 2006. The major lineages of the coffee family (Rubiaceae, Angiosperms). Combined analysis (nDNA and cpDNA) to infer the position of Coptosapelta and Luculia, and supertree construction based on rbcl, rps16, trnL-trnF and atpB-rbcl data. A new classification in two subfamilies, Cinchonoideae and Rubiodeae. Syst Geogr Pl 76: 85-146.

Schilthuizen M, Liew TS, Elahan B, Lackman-Ancrenaz I. 2005. Effects of karst forest degradation on pulmonate and prosobranch land snail communities in Sabah, Malaysian Borneo. Conserv Biol 19(3): 949954. DOI: $10.1111 / \mathrm{j} .1523-1739.2005 .00209 . x$

Sinsin B, Assede EM, Adomou AC. 2012 Magnoliophyta, Biosphere of Pendjari, Benin. Check List 8(4): 642-661. DOI: 10.15560/8.4.642

Sintayehu D. 2018. Impact of climate change on biodiversity and associated key ecosytem services in Africa: A systematic review. Ecosyst Health Sustain 4(9): 225-237. DOI: 10.1080/20964129.2018.1530054

Sohmer SH, Davis AP. 2007. The Genus Psychotria (Rubiaceae) in the Philippine Archipelago. Botanical Research. Institute of Texas Press, Texas.

Tobgay, Sridith K. 2019. Distribution pattern, composition, and diversity of the Rubiaceae species along the altitudinal gradient of the Himalayas in Western Bhutan. Songklanakarin J Sci Technol 41(5) 1037-1047.

Tolentino PJ, Navidad JR, Delos Angeles M, Fernandez DA, Villanueva EL, Obena RD, Buot I. 2020. Biodiversity of forests over limestone in Southeast Asia with emphasis on the Philippines. Biodiversitas 21(4): 1597-1613. DOI: 10.13057/biodiv/d210441

Villanueva EL, Fernandez DA, Delos Angeles M, Tolentino PJ, Obeña RD, Buot IJ. 2021. Biodiversity in forests over limestone in Paranas, Samar Island Natural Park (SINP), A UNESCO world natural heritage site nominee. Trop Nat Hist 21(1): 119-145. Retrieved from https://li01.tci-thaijo.org/index.php/tnh/article/view/243799

Watson L, Dallwitz MJ. 1992 onwards. The Families of Flowering Plants: Description, Illustrations, Identification, and Information Retrieval. Version: $14^{\text {th }}$ December 2000

WCSP. 2021. World Checklist of Selected Plant Families. Facilitated by the Royal Botanic Gardens, Kew. https://wcsp.science.kew.org/cite.do [January 10 2021]. 